Hymer8 (CPE)

(Final version)

\title{
Intra-Industry FDI, Uneven Development and Globalisation: the Legacy of Stephen Hymer
}

\author{
Nigel Driffield and James H Love \\ Economics and Strategy Group \\ Aston Business School \\ Aston University \\ Birmingham B4 7ET \\ UK \\ n.l.driffield@aston.ac.uk \\ j.h.love@aston.ac.uk
}

\begin{abstract}
This paper revisits the issue of intra-industry foreign direct investment. This issue was considered in Stephen Hymer's early work, but was not subsequently developed, and was largely ignored in the literature for some time. Using the example of the UK, this paper traces the patterns of intra-industry FDI, both across countries and industries, for both the manufacturing and service sectors. Despite the undoubted increase in the integration of goods and factor markets since the time of Hymer's writing, the analysis presented here shows that the pattern has changed little in the last forty years. The paper then goes on to discuss the motives for intraindustry FDI, relating it to technology flows and factor cost differentials. Finally, we present some analysis relating intra-industry FDI to uneven development, both between developed and developing countries, and between regions of a developed country. It is clear that intra-industry FDI is still very much a developed country phenomenon, as Hymer suggested, with both developing countries and poorer regions of developed countries unlikely to reap any of the benefits. In this context, one-way and two-way FDI must be seen as different phenomena within the debate on globalisation.
\end{abstract}

\section{Acknowledgement}

The authors are grateful for the comments of David Bailey, Christos Pitelis and three anonymous referees. Nigel Driffield acknowledges the support of the ESRC under award RES-000-22-0468. 
In recent years both academics and policy makers have expressed concern that increasing globalisation, both in the form of foreign direct investment (FDI) and international trade, is causing dramatic changes in labour demand in the developed world (see, for example, Wood 1994, 1998, and Anderton and Brenton 1999). Specifically, it has been suggested that demand for unskilled workers in the US and Western Europe has been, and will continue to decline dramatically, as the employers of unskilled workers face significant competition from the newlyindustrialising countries and other parts of the developing world. Allied to this are concerns that many global industries are becoming dominated by a few firms which engage in large scale FDI and control large proportions of both trade and investment in certain sectors.

These are not new concerns. In a series of classic works Stephen Hymer addressed the determinants and likely causes of FDI, and so formed the basis of the modern discipline of international business (Hymer 1960, 1976, 1971). From the outset Hymer considered the issue of intra-industry foreign direct investment (IIFDI), a phenomenon which he regarded as being not only entirely consistent with his international production approach to explaining FDI, but the very archetype of it. Here was a form of international capital movement which, by definition, could not be explained by interest rate differentials, and where some other more plausible explanation had to be sought. Intra-industry FDI therefore formed a crucial part of Hymer's theoretical analysis. Although Hymer considered IIFDI be sufficiently common to be worthy of study, he did not pursue the issue at length in his subsequent writings: indeed, the phenomenon was largely ignored for many years, and was not reconsidered to any significant degree until international business scholars and economists became interested in game theoretic approaches to FDI in the 1980s following Graham (1978).

A re-evaluation of Hymer's analysis is timely ${ }^{1}$. Although standard theoretical explanations of the multinational enterprise are now well understood, following the seminal works such as Buckley and Casson (1976) and Dunning (1979, 1988), theory has struggled to explain satisfactorily the

\footnotetext{
${ }^{1}$ We restrict the discussion to intra-industry FDI and uneven development. For a fuller evaluation of Hymer in the context of modern developments in international business see Dunning and Pitelis (2004).
} 
proliferation of intra-industry FDI. Early attempts (e.g. Dunning and Norman 1985, Graham 1985, and Rugman 1985) largely tried to explain the phenomenon within the confines of the existing prevailing theory, notably Dunning's OLI framework. While explanations of FDI based mainly on firm-specific advantage do not fit well with the phenomenon of intra-industry FDI, of perhaps more relevance are the more recent theoretical approaches to FDI, when considered alongside the importance of location. These explanations of FDI have relied on the 'new IO' literature, based on game theory or rivalry action. Rowthorn (1992), for example, shows that FDI will be dependent on market size. In addition, Rowthorn demonstrates that multinational firms undertake FDI to protect their home markets, viewing FDI as an aggressive phenomenon within a model of reciprocal investments. Firms from large countries may even seek to undertake FDI with the aim of defeating the competition from host country firms, thus extending their monopoly. Bhagwati et al. (1992), show that FDI occurs in order to facilitate tariff jumping. This is particularly pertinent to cases where industries or governments are concerned with the problem of 'job exporting'.

In this paper we revisit Hymer's approach to the issue of IIFDI, and suggest a link between Hymer's work on intra-industry FDI and his later analysis of FDI as a generator of uneven development (Hymer 1971). Using the UK as an example, we examine the pattern of inward and outward FDI to examine the scale and scope of, and motivation for, intra-industry FDI across countries and industries. We find patterns of IIFDI which suggest that Hymer's interest in the subject was well placed, but that he may have underestimated the extent and motivational importance of it. We then use the pattern of motivational influences to generate hypotheses on the possible effects of intra-industry and one-way FDI, and argue that this forms a link with Hymer's subsequent analysis of multinational enterprises as instruments of uneven development, and with the current debate on globalisation. This analysis can be extended to differential effects on regions of a large developed economy, as well as the more commonly considered distinctions between rich and poor countries. 


\section{HYMER, INTRA-INDUSTRY FDI, AND UNEVEN DEVELOPMENT}

For Hymer (1960, 1976), the existence of 'cross investment' - the tendency for direct investment to flow simultaneously in both directions between two countries - was at the very heart of his thesis highlighting the difference between direct and portfolio investment. In the opening chapter of his thesis, Hymer stresses the importance of the intra-industry nature of such cross investment: "Furthermore, and this is very important, cross investment often occurs within industries." (p. 22). He compares two major oil companies, one American (Standard Oil) and one Dutch (Royal Dutch Petroleum). Both companies invest and borrow in each other's countries and elsewhere in the world within the same industry, a phenomenon which is difficult to explain in terms of interest rate differentials, but “... in the theory of direct investment that is proposed in this thesis, the behavior is not at all strange but is in fact exactly what one would expect.” (p. 16)

From the outset, therefore, intra-industry investment was seen by Hymer as an integral part of the theory of international production. The reason for this is simply because IIFDI represented the archetypical example of exactly the kind of phenomenon he was interested in highlighting. For Hymer, it was impossible to explain IIFDI adequately using a theory of portfolio investment based on interest rate differentials ${ }^{2}$; rather, Hymer sought to explain capital flows in terms of the advantages and profitability of individual firms. This was of the essence for his theory of international operations, a theory which depended not on the incentives for arbitrage and capital movements provided by international interest rate differentials, but by the desire to control productive assets in other countries. This is expressed in terms of either removing competition between enterprises or appropriating fully the returns on certain skills and abilities in conditions of imperfect product and factor markets. "The motivation for the investment is not the higher interest rate abroad but the profits that are derived from controlling the foreign enterprise.” (p. 26). Here was a motivation for international (direct) investment which could explain the existence of cross-investment, even within a single industry, and which appeared to fit with the facts.

\footnotetext{
${ }^{2}$ Although this, of course, is precisely what Aliber (1970) attempts to do. Significantly, however, Aliber’s theory depends critically on imperfections in capital markets.
} 
After developing the theory of international operations Hymer turns in chapter 4 of his thesis to looking at the empirical evidence of international investment in manufacturing, and highlights five issues which are compatible with his theory of direct investment:

i) Some US industries have more foreign investment than others.

ii) A few firms in a few industries account for much of US FDI.

iii) Industries with a lot of foreign investment tend to be relatively highly concentrated.

iv) Most foreign investment is undertaken by large firms.

v) The existence of cross investment, and particularly intra-industry investment.

The last of these is given considerable prominence in supporting Hymer's thesis:

"One of the most interesting aspects of international operations is that in many of the industries where American firms have substantial foreign operations, one of the firms operating in the United States is a foreign firm... The existence of cross investment is, it seems to me, impressive and not at all contradictory to the theory of international operations outlined earlier...It appears well worth further study. It occurs often enough to be important yet not often enough to be a general rule.” (pp. 119-120)

Despite this importance of IIFDI to Hymer's central thesis, it is perhaps surprising that he did not develop the issue in his subsequent writing ${ }^{3}$. Instead, his attention switched to the effects of FDI and multinational enterprises, and especially the potentially detrimental impact of multinationals on economic development. In 'The Multinational Corporation and the Law of Uneven Development' (Hymer 1971), he envisaged a global economy in which giant multinational firms were so powerful that their scope and the spatial distribution of their managerial operations would have a direct influence on uneven economic development between the nations and regions of the world. Here, routine, day-to-day activities are spread around the world in search of location economies and maximum market access opportunities. The coordination of these routine activities is spatially more concentrated, as there is a need for the multinational enterprise

\footnotetext{
${ }^{3}$ There is a brief mention of cross-investment in Hymer (1972), but this goes little further than his $1960 \mathrm{PhD}$ dissertation.
} 
to access more skilled workers and international communication systems, with the top management responsible for strategic planning highly concentrated in a few major global cities. Beneath them lesser cities are organised on a hierarchical basis ranging from regional headquarters to offices dealing with routine operations. The limited opportunities for movement of staff within this hierarchy, especially the indigenous staff in the lower-level offices, served to perpetuate a hierarchy of uneven development and dependence, spatially determined by the activities of the multinationals.

While Hymer's analysis of uneven development had a considerable impact on the policies towards FDI initiated by several Third World countries in the 1960 s and $1970 \mathrm{~s}^{4}$, it is often now regarded as over-simplified, and at odds with the prevailing empirical evidence on the beneficial effects of FDI, and with the majority of national and international policies which are geared towards encouraging rather than restricting the flow of international capital. National and regional governments have a long history of offering financial and other inducements to multinational enterprises in order to encourage the establishment of local production facilities. While this is done partly in order to benefit from expected direct and indirect employment increases, there is a recognition among many agencies that the benefits of FDI may go far beyond those of employment. From a welfare perspective, encouraging inward investment may be justified if the social returns to FDI exceed the private returns. In practice, such an effect is usually regarded as being most likely in terms of productivity spillovers: local firms derive some benefit from gaining access to the firm-specific knowledge that accompanies inward FDI. Numerous empirical studies during the 1990s indicated that such productivity spillovers from FDI were real and substantial (for a review of this literature see Blomström and Kokko, 1998 and Görg and Greenaway, 2004), which undoubtedly further encouraged policy movements in favour of promoting inward investment.

However, recent developments suggest that Hymer's analysis of the contribution of MNEs to uneven development may not be entirely misplaced. First, recent empirical work in the economics literature has begun to question the extent of (horizontal) productivity spillovers, 
especially when the analysis is carried out at the level of the firm rather than the industry (Görg and Strobl 2001). Since much of the presumed (indirect) benefit of FDI depends on the existence of such spillovers, this is an interesting development. In addition, there is now evidence both that the motivation for FDI has an important effect on the existence and extent of spillovers, and that spillovers do not run one way from foreign firms to their domestic counterparts. Specifically, Driffield and Love (2002) show that only FDI motivated by the desire to exploit the multinational's ownership advantage leads to positive productivity spillovers, while that motivated by the desire to access the superior technology of the host country actually has a negative effect on domestic productivity, while Driffield and Love (2003) provide evidence for 'reverse spillovers' i.e. that technology generated by the domestic sector spills over to foreign MNEs, but that this effect is restricted to relatively R\&D intensive sectors. In many ways, these findings mirror the results reported for FDI spillovers in developing countries, which are rather ambiguous. For example, Aitken and Harrison (1999) report a negative industry-level relationship between FDI and productivity growth in the domestic sector for Venezuela, while Kathuria (2000), Kokko et al (2001) and Kugler (2005) report ambiguous or conflicting results for various developing countries.

Second, there is also significant evidence of heterogeneity in the motivation for FDI with developed countries. One can point to the fact that MNEs clearly do seek to structure their international operations in ways that exploit location economies, and so contribute to a spatial hierarchy. For example, Young and Hood (1993) document the ways in which multinational firms make use of research and consultancy advice on the optimal sites in which to locate different activities across Europe, with centralised functions such as R\&D frequently located in the heart of Europe, while more peripheral areas are regarded as more attractive for assembly operations. Third, the analysis so far has considered only inward FDI. In a study of FDI flows between major industrialised countries over twenty years, van Pottelsberghe de la Potterie and Lichtenberg (2001) find that outward FDI makes a positive contribution to domestic productivity in the home country; by contrast, inward FDI has no such effect. The presumed mechanism for this is that spillover effects are generated by accessing the foreign R\&D capital stock in target

\footnotetext{
${ }^{4}$ Harry Johnson (1970) was particularly critical of work such as Hymer's for encouraging the development of policies by many national governments which sought to restrict inward direct investment, policies which Johnson
} 
countries. They therefore conclude that FDI flows are predominantly technology sourcing in nature, and that inward FDI in particular represents a 'Trojan horse', motivated principally by the desire to take advantage of the technological base of host countries. This suggests that any analysis of the impact of FDI on development must take account of inward and outward FDI, in accord with Hymer's emphasis on the role of cross-investment.

In the remainder of this paper we re-examine the issue of cross-investment to see whether Hymer's insights have stood the test of time. Using data at the sectoral level, by home and host country, on inward and outward FDI for UK industry, we consider three issues:

1. Is intra-industry cross investment a significant element of total FDI, as Hymer hypothesised?

2. Is the motivation for intra-industry cross investment different from one-way FDI flows, and what is the pattern of these motivational influences?

3. Is there any evidence of a link between intra-industry cross investment and uneven economic development?

The first two questions are clearly directly linked to the issues raised by Hymer in his 1960 dissertation. The third is more speculative and tries to establish whether there is any connection between Hymer's earlier and later writings. It may be thought that the use of modern data is a rather unfair test of Hymer's hypotheses; both goods and factor markets are far more integrated than they were forty years ago, and many more countries are engaged in outward FDI than was the case when Hymer wrote his dissertation. Nevertheless, we will argue that Hymer's analysis is still applicable today to a remarkable degree, and that the insights that he provided are still relevant. Indeed, it may even be argued that the most striking result of our analysis is how little the situation has changed since Hymer made his observations.

\section{THE PATTERN AND EXTENT OF INTRA-INDUSTRY FDI IN THE UK}

The data employed in the analysis comprise inward and outward FDI flows to (from) the UK from (to) 42 major investing countries for 23 2-digit manufacturing and service sectors from 
1981 to 1996 (though only available annually from 1987 onwards) ${ }^{5}$. These data illustrate how little the pattern of intra-industry FDI appears to have changed since Hymer first considered this issue. Figure 1 illustrates that even as recently as 1996, IIFDI still accounted for over $90 \%$ of all FDI flows to and from the UK. While there has been some variation since 1981, the percentage of FDI that is intra-industry is consistently high. The scale and scope of both inward and outward FDI in the UK is well understood, so it is perhaps surprising that the relative importance of intraindustry FDI has not diminished over the period. This is even more remarkable when one considers the industrial and geographic patterns of intra-industry FDI over time. To do this we use the standard measure of intra-industry FDI:

$$
I I F D I_{i j}=\frac{O F D I_{i j}+I F D I_{i j}-\left|O F D I_{i j}-I F D I_{i j}\right|}{O F D I_{i j}+I F D I_{i j}}
$$

where IFDI is inward FDI; OFDI is outward FDI; $\mathrm{i}=$ industries $1 \ldots \mathrm{n} ; \mathrm{j}=$ countries $1 \ldots . . \mathrm{r}$. This measure therefore takes the value 1 where inward and outward FDI are equal, and 0 where FDI is all one way. It is analogous to the Grubel-Lloyd index of intra-industry trade (Grubel and Lloyd 1975), and is the standard measure in empirical analysis of intra-industry FDI (Greenaway et al 2001).

Tables 1 and 2 present the average values of the measure of intra-industry FDI flowing to/from the UK for industries and countries respectively. Thus in Table 1 IIFDI $_{\mathrm{ij}}$ is averaged across countries at the 2-digit level, while in Table 2 IIFDI $_{\mathrm{ij}}$ is averaged across sectors. What is striking in both tables is how concentrated intra-industry FDI is, even as late as 1996. Table 1 shows that intra-industry FDI is concentrated in perhaps seven of the 23 sectors, largely those that are seen as being 'globalised' such as financial services, transport equipment, paper and printing and mechanical and electrical engineering. The table also illustrates that certain sectors traditionally thought of as having high levels of intra-industry FDI, such as chemicals, food and drink or textiles, have seen dramatic reductions in the scale of intra-industry FDI, largely because of the increase in the geographical spread of outward FDI from the UK, while inward FDI into the UK

\footnotetext{
${ }^{5}$ Table A1 in the appendix lists these countries and sectors in full. Figure 1 is compiled using the measure of IIFDI discussed in the text.
} 
has if anything become more concentrated in terms of source countries. It is also noticeable that certain sectors such as rubber have high levels of intra-industry FDI, largely because FDI to and from the UK is concentrated in just a few countries. Finally, the data also show that intraindustry FDI is high in sectors such as services and distribution, perhaps suggesting that MNEs enter each other's markets through distribution or services rather than manufacturing.

The country-specific averages of IIFDI intensity are perhaps more informative (Table 2$)^{6}$. These suggest that intra-industry FDI is concentrated in just a few countries, notably the EU states and North America. The figures for these countries are largely stable over time, as are the number of industries with either one-way or two-way FDI in each country. One country that shows a large increase in intra-industry FDI with the UK is Japan, largely as a result of a twelve-fold increase in UK outward FDI to Japan over the period. These is some evidence of intra-industry FDI becoming less important in some of the smaller countries such as Holland, Belgium and Finland, as increased integration appears to have reduced FDI flows from the UK to these countries. This confirms the likely relationship between FDI, market size and transport costs suggested by Rowthorn (1992) in a formal re-statement of Hymer and Rowthorn (1970). This suggests that market size is an important determinant of intra-industry FDI, and that as artificial trade costs are reduced then intra-industry trade will increase as intra-industry FDI becomes less attractive. It is also clear, confirming what Hymer wrote nearly forty years ago, that not only is intra-industry FDI a function of country size, but also strongly related to the levels of development. South Korea and Russia, for example developed their manufacturing and trading sectors relatively rapidly in the latter part of the period, leading to outward FDI. Interestingly, there is no intraindustry FDI with China in this period, as the data show no outward FDI from China to the UK.

Clearly, therefore, Hymer was correct in his assertion that IIFDI was an important phenomenon; indeed he may have significantly underestimated the extent of intra-industry FDI. Forty years after his analysis was undertaken, the vast majority of FDI flowing from and to the UK is of this type, and it demonstrates a geographical and sectoral pattern consistent with Hymer's analysis. We now turn to the motivation for, and possible effects of, intra-industry FDI.

\footnotetext{
${ }^{6}$ For reasons of space, countries with no intra-industry FDI with the UK are omitted from the table.
} 


\section{THE MOTIVATION FOR (INTRA-INDUSTRY) FDI}

\section{Conceptual taxonomy}

We begin by developing a simple taxonomy of motivation for FDI, building on the theoretical and empirical literature, and extending the analysis of Love (2003) and Driffield and Love (2002) on technology sourcing versus technology exploiting as a motivation for FDI. This taxonomy allows for both ownership and locational influences on FDI flows (Figure 2).

The classic 'ownership' advantage involves some form of technological superiority; thus where a company has some competitive advantage over its rivals, and where for reasons of property rights protection licensing is unsafe, a company will set up production facilities in a foreign country through FDI, as long as there are specific advantages in the host country which make FDI preferable to exporting. This traditional analysis of why a firm seeks to undertake FDI is articulated by Buckley and Casson (1976) and Dunning (1979, 1988, 1993). The necessary condition within this framework for a firm to undertake FDI is that it owns an asset that provides some essential advantage for the inward investor over host country firms. More recent literature, based on Cantwell (1989, 1991) or Pearce (1999) has characterised such advantages being generated through R\&D, and linked to the exploitation of economies of scale. Indeed, recent applied work in this area attempting to characterise ownership advantages in a given location suggests that new technology and quality of the capital stock are key variables (see, for example, Oulton 2001, Griffith 1999, Griffith and Simpson 2001 and Criscuolo and Martin 2004).

This is the technology exploiting motivation. However, recent theoretical work has given renewed impetus to something long recognised in the literature, that a possible motive for FDI is not to exploit proprietary technology, but to access it: thus technology sourcing may be the motive for FDI. Typically, research in this area is founded in the 'new IO' literature, based on game theory or oligopolistic interaction. Rowthorn (1992), for example, shows that multinational firms undertake FDI to protect their home markets, while Bhagwati et al. (1992) show that FDI occurs in order to facilitate tariff jumping. Fosfuri and Motta (1999) question the need for firmspecific advantages to give rise to multinational activity, and provide a formal model of FDI in 
which the motivation is not to exploit existing technological advantages in a foreign country, but to access such technology and transfer it from the host economy to the investing multinational corporation via spillover effects. In a related analysis, Kuemmerle (1999) distinguishes between 'home-base exploiting' (HBE) FDI and 'home-base augmenting' (HBA) FDI. The former is undertaken in order to exploit firm-specific advantages abroad, while the latter is FDI undertaken to access unique resources and capture externalities created locally ${ }^{7}$. This possibility has had some policy influence in the United States and Europe, with concerns that the technological base of these economies may be at risk through the technology sourcing activities of Japanese and US corporations respectively (Kogut and Chang 1991; Neven and Siotis 1996) ${ }^{8}$.

The focus on technology in explaining flows of FDI, however, ignores the second pillar of Dunning's (1979) analysis of FDI, location advantage. We therefore extend the analysis of the technology exploitation/sourcing motivation by allowing for the key element of locational influence. The analysis here concerns the benefit conferred on the organisation by its decision to operate in a particular host location. This is generally related to country specific phenomena, or, within the international economics literature, the factor endowments of a particular country or region. The importance of location advantage within the context of FDI and development is discussed by Narula and Dunning (2000): they focus on the heterogeneity of location in the context of factors that act to attract FDI, though largely from the perspective of the ability of policy makers to attract FDI in developing countries. The analysis of Narula and Dunning does, however, highlight the distinction between 'efficiency seeking' and 'market seeking' FDI attracted to developing countries. Our analysis aims to extend this, by combing this with the technology sourcing/ technology exploiting distinction outlined above, acknowledging that in terms expressed by Narula and Dunning (2000) 'ownership' and ‘location’ phenomena may not be discussed separately when considering heterogeneity in FDI.

The economics literature consistently shows empirically that factor cost differentials, and in particular unit labour cost differentials (wages adjusted for productivity differences), are an

\footnotetext{
${ }^{7}$ A similar idea is evident in the 'strategic asset seeking behaviour' identified by Dunning and Narula (1995).

${ }^{8}$ However, in a detailed analysis of US direct investment flows, Love (2003) finds little evidence of technology sourcing as a motivation for FDI.
} 
important determinant of FDI flows. This is evident even in FDI between advanced industrialised economies (Pain, 1993; Bajo-Rubio and Sosvilla-Rivero, 1994; Barrell and Pain, 1996; Love and Lage-Hidalgo, 2000; Love, 2003). Thus, we have a simple model illustrating the alternative motivations for FDI, based on technology differences and factor cost differences (Figure 2). Crucially, this is at the sectoral level within countries, not merely at the national level. Technology is measured by $R \& D$ intensity (RDI) differentials ${ }^{9}$, while costs are measured in terms of unit labour costs.

The quadrants on the top row both have some technology sourcing element. The top-left quadrant is where the host economy is more $R \& D$ intensive and has lower unit labour costs than the source investor (at the industry level). This implies inward investment which is technology sourcing and has the additional advantage of exploiting the host's locational advantage (lower unit labour costs). The top-right quadrant is 'pure' technology sourcing investment, attracted by the host's higher R\&D intensity despite its higher unit labour costs. The quadrants on the bottom row of Figure 2 both have technology exploitation, that is the traditional ownership advantage, as the key motivational element. The bottom-left quadrant has the additional advantage of lower host unit labour costs, suggesting an 'efficiency seeking' motivation (Dunning, 1998). The final quadrant is the 'pure' ownership advantage motivation, where source-country R\&D intensity is greater than that of the corresponding host sector and FDI occurs despite the host sector having higher labour costs ${ }^{10}$.

\section{The motivational pattern of FDI for the UK}

The analysis now turns to a sub-sample of the data used earlier, largely manufacturing, and covering the main FDI partners of the UK. Data on unit labour costs and R\&D intensities for non-OECD countries are scarce, and so our analysis is limited to those OECD countries with which the UK has significant FDI flows. The data employed in the analysis comprises inward

\footnotetext{
${ }^{9}$ There are numerous measures of R\&D intensity, such as the share of total national R\&D, or the share of worldwide industry level R\&D. However, as we wish to compare international R\&D intensities at the sectoral level, we use $\mathrm{R} \& \mathrm{D}$ as a proportion of value added, in order to remove simple size effects.

${ }^{10}$ We recognise, of course that labour costs not the only possible locational advantage, and accept that this simple taxonomy appears to ignore so-called 'resource seeking' FDI. However, the availability of natural resources will be strongly related to efficiency, and so this effect should be captured in Figure 2.
} 
and outward FDI flows to (from) the UK from (to) 13 major investing countries for 11 manufacturing sectors and 9 years (1987-95). These countries include all of the major direct investors into and out of the UK and collectively account for over $90 \%$ of the total overseas direct investment flows to and from the UK over the relevant period. The manufacturing sectors are at the two digit level, the lowest level of aggregation compatible with combining Office for National Statistics (ONS) and OECD data for the relevant countries. The data on FDI outflows and inflows were provided by ONS; data on international sector-specific R\&D intensities were derived from the OECD's ANBERD and STAN databases, for R\&D expenditure and value added respectively; unit labour cost data were also provided by the OECD. Details of the countries and sectors in the sub-sample can be found in the Appendix (Table A1).

Taking the UK as the host economy for inward FDI, Figure 3a is identical to Figure 2. Figure 3b shows the same four-quadrant diagram, but this time taking the UK as the source country (i.e. FDI flows from the UK). Here the motivations listed in each quadrant are of course the reverse of 3a, because the UK is now the home country. The patterns of inward and outward investment show some marked differences. Only $27 \%$ of investment flowing into the UK is from counties with higher sectoral unit labour costs. By contrast, over $80 \%$ of outward FDI goes to destinations with lower unit labour costs than the UK, with the majority of it (50\% of total outward FDI) going to countries with higher R\&D intensity than the equivalent UK industry. The main destinations for this investment is the United States, France and Germany; the fact that these relatively high-wage economies have lower unit labour costs than the UK in certain industries suggests a productivity difference motivation for FDI from the UK. This in turn suggests potential difficulties for UK unskilled workers: they face competition not only from low wage economies, but also from high-wage economies with higher productivity. Figures 3a and 3b also indicate that technology sourcing is also a major motivating factor for outward FDI (61\%) but not for inward FDI (24\%), perhaps giving dome credence to the argument of van Pottelsberghe and Lichtenberg (2001) that much outward FDI is undertaken with a view to receiving beneficial spillovers resulting from the accessing of foreign $R \& D$ stocks.

Figure 4 shows the same four-quadrant diagram, but this time separately for intra-industry FDI and one-way FDI. Given the dominance of intra-industry FDI in overall UK FDI, one might 
expect the motivational patterns of IIFDI and one-way FDI to be identical. For inward investment, the IIFDI and one-way FDI patterns are indeed virtually identical, and therefore very similar to the overall investment pattern. However, there are marked differences between the IIFDI and one-way investment patterns for outward investment flows. Both IIFDI and one-way FDI display the tendency to flow predominantly to destinations with lower unit labour costs than the UK, but $75 \%$ of IIFDI derives from technology sourcing and/or locational advantage motivations while only $14 \%$ of one-way FDI is motivated by these influences. The vast majority (77\%) of outward one-way FDI is motivated by ownership advantage/efficiency seeking influences i.e. takes place in sectors in which the UK has both higher R\&D intensity and higher unit labour costs than the host economy: less than one-fifth of IIFDI flows from the UK displays this pattern. This undoubtedly reflects the industry and country pattern of UK FDI revealed in Tables 1 and 2, with UK companies investing in low-wage sectors/economies which do not themselves invest in the $\mathrm{UK}^{11}$.

This analysis of FDI motivation illustrates three key issues. The first is the importance of the ownership advantage for FDI into the UK. More than three-quarters of total inward FDI is motivated by some ownership advantage, and $60 \%$ of this occurs despite the UK having some unit labour cost disadvantage compared with the source economy. Second, low unit labour costs are a crucial determinant of FDI flowing from the UK. Finally, and most germane to the present discussion, is the motivational pattern of intra-industry FDI. Despite the predominance of IIFDI in total UK foreign direct investment, there is clear evidence of a different motivational pattern between intra-industry and one-way investment out of (but not into) the UK.

\section{INTRA-INDUSTRY FDI AND UNEVEN DEVELOPMENT}

Starting with the motivational taxonomy, one can demonstrate, following Driffield and Love (2002), that FDI motivated by different factors will have different impacts on both host and source countries. In Figure 3a for example (inward investment into the UK), the beneficial

\footnotetext{
${ }^{11}$ It should be noted that due to the lack of comparable R\&D data, several potential host countries for one-way outward FDI are excluded from our analysis, notably China, Vietnam and Malaysia. It is reasonable to assume that all the FDI from the UK to such locations is in the $R \& D_{U K}>R \& D_{H}, U L C_{U K}>U L C_{H}$ category, so if anything the
} 
effects of inward investment are likely to be limited to sectors in the bottom right quadrant. Here, inward FDI introduces superior technology into the UK, and into relatively high wage industries. Such industries would be expected to be able to assimilate any new technology, thus maximising technological externalities, as well as experiencing growth effects and possibly efficiency effects. There is a large literature on externalities from inward FDI and the importance of absorptive capacity, catching up, and the ability to assimilate externalities; see for example Blomström et al (2001) for a summary, or more recently Keller (2004). In the context of inward investment into the UK, this suggests that investment into the South East of England will have the greatest technology transfer effect, with the region gaining from spillovers and the creation of skilled employment.

However, Figure 3a also suggests that a large proportion (over 25\%) of inward investment into the UK is into sectors where labour costs are lower in the UK than they are in the source country. This is indicative of the types of inward investment projects that most often receive media coverage, often greenfield investment in regions of high unemployment. While such investment generates employment, it is far less likely to generate further social returns in the form of technology spillover or upskilling effects. This is discussed in some detail in Driffield and Taylor (2000), and in the context of regional disparities in Bailey and Driffield (2003). Figure 3a also illustrates that 22\% of inward FDI may be considered technology-sourcing FDI, in the sense that R\&D intensities are lower in the source country than in the UK. More than half of this is in industries where UK labour costs are above those of the source country at the industry level, so efficiency seeking cannot be the motivation for entry into the UK. This gives support to the arguments of Coe and Helpman (1995) and van Pottelsberghe and Lichtenberg (2001) that FDI acts as a vehicle for international technology transfer. It would appear, however, that this is a phenomenon limited to transfers between developed countries. This provides significant support not only for Hymer's hypothesis that FDI in general is associated with increased disparities between rich and poor countries, but that intra-industry FDI in particular is associated with this process. The data presented in Table 2 suggest that certain countries, such as the Czech Republic or Russia have reached the stage of development where intra-industry FDI becomes feasible, but

estimate of $77 \%$ in table $4 \mathrm{f}$ may be an underestimate. As the data indicate that there is no inward FDI from these countries, the other tables are unaffected. 
the number of countries that have generated intra-industry FDI from a base of zero over the period is limited to those two.

Turning now to the importance of outward FDI, Figure 3b suggests that over $80 \%$ of outward FDI from the UK is targeted at locations with lower unit labour costs than the UK. This suggests that the beneficial effects to the host country are likely to be limited to employment and export generation, and some limited exposure to relatively low level imported technology. The relatively well-publicised relocations of Dyson to Malaysia and Dr Martens to China are perhaps good examples of this type of outward FDI. While it is likely that such FDI is beneficial to the competitiveness of UK firms overall, in the traditional mode of $R \& D$ being done at home with low value activities transferred abroad, this is again suggestive of the uneven development hypothesis suggested by Hymer. Such efficiency-seeking FDI is probably beneficial to the owners of capital, and to skilled labour in developed countries, while it has a detrimental effect on the returns to unskilled labour in developed countries. Regions of the UK suffering from structural unemployment are likely therefore to be the main losers in this process, such that both outward and inward FDI act to increase inequalities between regions, and between occupational groups, even within a developed, industrialised economy.

\section{Does intra-industry FDI exacerbate uneven development?}

One reason for focussing here on intra-industry FDI as a distinct phenomenon is that the distribution of one-way and intra-industry FDI is very different across the quadrants of Figure 2. Intra-industry FDI is very much a developed world phenomenon, and so is relatively unlikely to impact on the demand for unskilled workers. Figure 4 illustrates this: the proportion of outward FDI from the UK going to countries with lower labour costs is higher for one-way than for intraindustry FDI. Figure 4 particularly demonstrates that one-way FDI conforms far more closely to the standard explanations of FDI than does intra-industry FDI. This may well explain why there has been so little focus on intra-industry FDI within the international business literature. Many explanations for intra-industry FDI are based on the analysis of intra-industry trade and the concept of vertical differentiation - the developed world carrying out high value-added activities with the developing world focussing on labour-intensive technology. The data presented here 
suggest that FDI contributes to this developmental process, but that the impacts of IIFDI and one-way FDI are probably very different. One-way outward FDI from the UK is far more focussed towards those host locations that are both cheaper and less technologically intensive than the UK. Indeed this quadrant accounts for $77 \%$ of one-way outward FDI, while only $19 \%$ of outward intra-industry FDI is of this type. This suggests that intra-industry FDI is explained by oligopolistic interaction between developed world multinationals, while one-way FDI out of the UK appears to be attracted to locations with low wage costs. As such, the uneven development concerns of intra-industry FDI are related to the extent to which this represents technology transfer between developed countries, with developing countries unable to access these flows of technology. One-way outward FDI from the UK represents UK multinationals seeking lower cost locations, with correspondingly limited flows of technology to the developing world.

Hymer foresaw a situation where low-level day-to-day activities would seek the lowest possible costs, while intra-industry FDI would represent an essential aspect of competition between leading firms. The analysis presented here suggests that in, Hymer's terms, intra-industry FDI represents competition between firms seeking to access each other's home markets by seeking to locate in global and regional centres. This is a potential explanation for why intra-industry FDI in the service, banking and distribution sectors has been high for the past twenty years, and appears to be growing. By contrast, one-way FDI spreads around the world in search of low costs and market access. To quote Hymer, global cities would become the "major centers of high-level strategic planning” (1971: 124) whilst lesser cities would be organised on a hierarchical basis ranging from bases for regional headquarters down to sites dealing with merely day-to-day operations. The data presented and discussed here are consistent with this, as sectors associated with high levels of technological competition through R\&D demonstrate high levels of intraindustry FDI. Such sectors include electrical engineering, transport and instrument manufacture. Hymer emphasised how FDI would perpetuate the system of 'trickle-down', where only basic technology is transferred to lower cost centres. This is illustrated by the reduced importance of intra-industry FDI in sectors such as chemicals and food; as technology becomes more standardised, FDI becomes efficiency seeking rather than technology sourcing. Further, traditional industries that are often thought of as being low technology sectors, such as textiles 
and paper, printing and publishing, have also seen a shift from intra-industry FDI to one-way outward FDI from the UK, towards lower cost locations.

\section{CONCLUSIONS}

The work of Stephen Hymer foreshadowed much of the modern debate on globalisation. Hymer's initial concern was to show that intra-industry FDI was a form of international investment which could not be explained by interest rate differentials, which had its own motivational patterns, and which was commonplace. In this he succeeded admirably. But what Hymer never did in any explicit sense was to link the issue of intra-industry FDI per se directly to his subsequent work on multinationals and uneven development. This paper represents an attempt both to place one aspect Hymer's work in a modern context, and to make a link between intra-industry FDI, uneven development and the globalisation debate.

The data presented above illustrate that intra-industry FDI is at least as important now as it was when Hymer presented his analysis more than forty years ago. It is therefore clear that Hymer was correct in his belief that intra-industry FDI was important both as a proportion of total global direct investment, but also because of its motivational influences. But the data also suggest that a link can indeed be made between intra-industry FDI and uneven development. It is evident that intra-industry FDI remains a developed world phenomenon, and so is strongly related with the 'top tier' of locations in Hymer's later analysis. There is some evidence of countries being able to make the leap to benefit from these two-way flows, but this seems limited to isolated industries in one or two countries. Intra-industry FDI in the UK is associated with technology. Inward intra-industry FDI largely follows that standard pattern of FDI described by Hymer and by Dunning (1958); it is associated with firms seeking to exploit their technological advantages over host country firms. Outward intra-industry FDI from the UK is largely associated with UK firms seeking to exploit the locational advantages offered by countries and sectors with higher $\mathrm{R} \& \mathrm{D}$ intensities but lower labour costs than the UK, traditionally a high wage country. This pattern is suggestive, as the data bear out, of inward investment FDI representing flows between the EU and North America, and more recently Japan. 
Thus, in Hymer's terms, intra-industry FDI does appear likely to foster further uneven development. European, North American and Japanese firms clearly engage in FDI in order to compete in each other's markets, and also to coordinate activities between global and regional centres. While this may be argued to be merely a symptom of uneven development rather than a cause, it is clear that increased flows of technologically motivated FDI between the so called 'triad' locations are limiting the exposure to new technology that other countries can have. Equally, one-way outward FDI from these developed countries is growing in scale and scope, seeking more efficient locations for low value-added activity. There is also evidence that the number of industries now seeking to do this is increasing, with call centres from the UK moving to India for example. This pattern of intra-industry FDI has implications for the less developed regions within developed countries, as multinational activity becomes more concentrated in 'high level' or strategic locations, and low production facilities is relocated abroad.

The arguments concerning the impacts of FDI in both host and source countries are discussed in many general texts on globalisation. Of particular relevance here are the arguments concerning the impact that capital flows have on the relative returns to skilled and unskilled labour (as well as capital) in both host and source countries. The analysis presented here suggests that intraindustry FDI is very much a 'developed world' phenomenon, with countries such as Russia and The Czech Republic appearing in the intra-industry FDI data once they have reached a given level of development. As such, in the terms expressed by Bhagwati (2004), for example, intraindustry FDI is unlikely to have an immiserising effect on either developing country workers, or unskilled workers in developed countries. It is more likely to lead to agglomerations of activity in certain sectors, in the way suggested by Hymer, with limited 'trickle down' development for developing countries. One-way outward FDI from developed countries may well have an immiserising effect on unskilled workers in developed countries, in the way outlined in the famous paper by Feenstra and Hanson (1999); but it is clear that in this context one-way and two-way FDI must be seen as different phenomena within the debate on globalisation. 
Figure 1: Intra-industry FDI as a proportion of total UK FDI

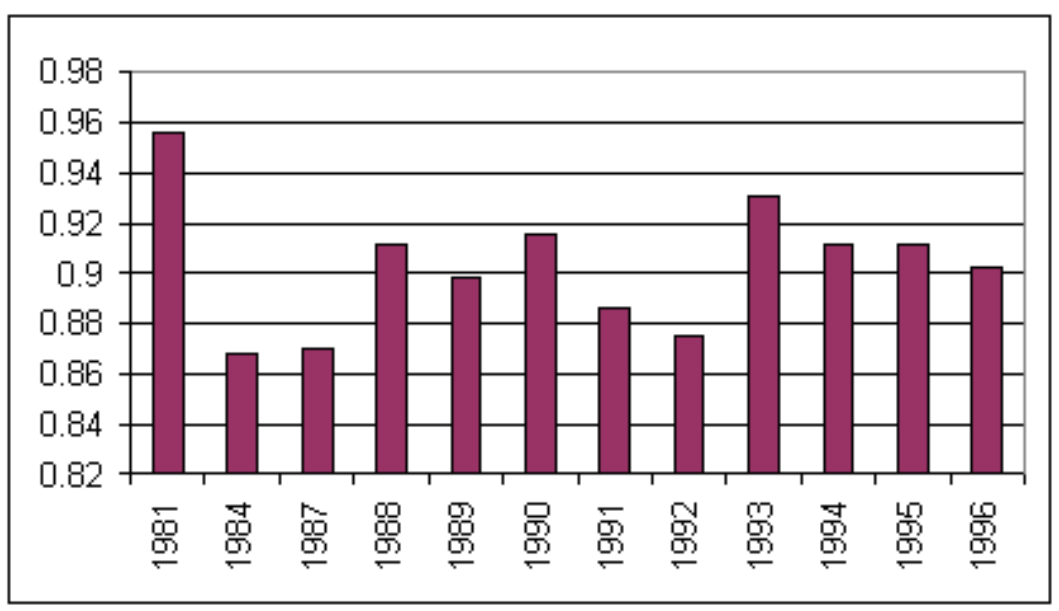


Table 1: Industrial patterns of UK intra-industry FDI.

\begin{tabular}{|c|c|c|c|c|c|c|}
\hline & 1981 & 1984 & 1987 & 1990 & 1993 & 1996 \\
\hline $\begin{array}{l}\text { Agriculture, forestry \& } \\
\text { fishing }\end{array}$ & 0.010 & 0 & 0 & 0 & 0 & 0 \\
\hline number of countries & 1 & 0 & 0 & 0 & 0 & 0 \\
\hline Chemicals & 0.167 & 0.150 & 0.150 & 0.221 & 0.097 & 0.073 \\
\hline number of countries & 9 & 5 & 5 & 7 & 5 & 5 \\
\hline Construction & 0.321 & 0.123 & 0.061 & 0.005 & 0.246 & 0.042 \\
\hline number of countries & 7 & 2 & 2 & 1 & 5 & 3 \\
\hline Distribution & 0.267 & 0.348 & 0.333 & 0.385 & 0.283 & 0.238 \\
\hline number of countries & 15 & 14 & 14 & 15 & 14 & 15 \\
\hline Electrical engineering & 0.222 & 0.191 & 0.148 & 0.153 & 0.204 & 0.249 \\
\hline number of countries & 11 & 6 & 5 & 7 & 8 & 9 \\
\hline Energy & - & 0 & 0 & 0.047 & 0.087 & 0.080 \\
\hline number of countries & 0 & 0 & 0 & 1 & 5 & 6 \\
\hline Food, drink, tobacco & 0.202 & 0.087 & 0.122 & 0.073 & 0.120 & 0.051 \\
\hline number of countries & 9 & 2 & 2 & 3 & 6 & 5 \\
\hline Hotels/Catering \& property & 0.065 & 0.091 & 0.003 & 0.049 & 0.026 & 0.075 \\
\hline number of countries & 5 & 2 & 1 & 2 & 2 & 2 \\
\hline Insurance Companies & - & 0.062 & 0.188 & 0.153 & - & 0.147 \\
\hline number of countries & 0 & 3 & 5 & 5 & 0 & 5 \\
\hline $\begin{array}{l}\text { Mechanical and instrument } \\
\text { manufacturing }\end{array}$ & 0.262 & 0.198 & 0.256 & 0.349 & 0.286 & 0.324 \\
\hline number of countries & 10 & 4 & 7 & 10 & 9 & 11 \\
\hline Metal manufacturing & 0.176 & 0.229 & 0.108 & 0.304 & 0.218 & 0.159 \\
\hline number of countries & 6 & 1 & 1 & 3 & 3 & 3 \\
\hline Other financial institutions & 0.258 & 0 & 0.153 & 0.092 & 0.159 & 0.040 \\
\hline number of countries & 7 & 0 & 3 & 4 & 5 & 5 \\
\hline Other manufacturing & 0.296 & 0.292 & 0.150 & 0.285 & 0.255 & 0.260 \\
\hline number of countries & 11 & 7 & 4 & 8 & 9 & 9 \\
\hline Other services & 0.178 & 0.121 & 0.254 & 0.129 & 0.237 & 0.128 \\
\hline number of countries & 11 & 5 & 7 & 6 & 12 & 11 \\
\hline $\begin{array}{l}\text { Paper, printing and } \\
\text { publishing }\end{array}$ & 0.308 & 0.123 & 0.082 & 0.195 & 0.141 & 0.191 \\
\hline number of countries & 6 & 2 & 2 & 4 & 5 & 5 \\
\hline Rubber & 0.153 & 0.176 & 0 & 0.034 & 0.312 & 0.186 \\
\hline number of countries & 5 & 2 & 0 & 1 & 3 & 4 \\
\hline Shipbuilding & 0 & - & - & - & 0 & 0.086 \\
\hline number of countries & 0 & 0 & 0 & 0 & 0 & 1 \\
\hline Shipping & 0.121 & 0 & 0.074 & 0.145 & 0.174 & 0 \\
\hline number of countries & 3 & 0 & 1 & 2 & 3 & 0 \\
\hline Textiles, leather, clothes & 0.493 & 0.031 & 0.132 & 0.090 & 0.100 & 0.087 \\
\hline number of countries & 7 & 1 & 3 & 2 & 3 & 2 \\
\hline Transport (excl shipping) & 0.080 & 0.096 & 0.124 & 0.093 & 0.160 & 0.363 \\
\hline number of countries & 6 & 4 & 4 & 4 & 9 & 7 \\
\hline Vehicles & 0.079 & 0.053 & 0.049 & 0.124 & 0.132 & 0.128 \\
\hline number of countries & 5 & 1 & 2 & 3 & 4 & 4 \\
\hline
\end{tabular}


Table 2: Geographical pattern of UK intra-industry FDI.

\begin{tabular}{|c|c|c|c|c|c|c|}
\hline country & 1981 & 1984 & 1987 & 1990 & 1993 & 1996 \\
\hline AUSTRALIA & 0.138 & 0.001 & 0.116 & 0.046 & 0.116 & 0.071 \\
\hline number of industries & 10 & 2 & 4 & 3 & 7 & 4 \\
\hline AUSTRIA & 0.228 & 0.158 & 0.068 & 0.127 & 0.033 & 0.053 \\
\hline number of industries & 4 & 1 & 1 & 1 & 1 & 1 \\
\hline BELGIUM & 0.340 & 0.189 & 0.164 & 0.212 & 0.129 & 0.076 \\
\hline number of industries & 10 & 4 & 4 & 6 & 5 & 2 \\
\hline CANADA & 0.289 & 0.126 & 0.177 & 0.179 & 0.325 & 0.260 \\
\hline number of industries & 14 & 5 & 5 & 6 & 9 & 9 \\
\hline CHINA & -- & 0 & -- & 0 & 0 & 0 \\
\hline number of industries & 0 & 0 & 0 & 0 & 0 & 0 \\
\hline DENMARK & 0.433 & 0.197 & 0.122 & 0.285 & 0.305 & 0.274 \\
\hline number of industries & 8 & 2 & 1 & 4 & 6 & 7 \\
\hline FINLAND & 0.024 & 0.490 & 0.311 & 0.267 & 0.058 & 0.087 \\
\hline number of industries & 1 & 1 & 1 & 1 & 2 & 1 \\
\hline FRANCE & 0.306 & 0.268 & 0.286 & 0.289 & 0.396 & 0.239 \\
\hline number of industries & 11 & 7 & 8 & 10 & 14 & 13 \\
\hline GERMANY & 0.335 & 0.301 & 0.308 & 0.226 & 0.349 & 0.343 \\
\hline number of industries & 12 & 9 & 10 & 9 & 13 & 11 \\
\hline HONG KONG & 0.148 & 0.014 & 0.001 & 0.030 & 0.050 & 0.007 \\
\hline number of industries & 6 & 2 & 1 & 2 & 3 & 2 \\
\hline IRISH REPUBLIC & 0.167 & -0.007 & 0.024 & 0.098 & 0.137 & 0.134 \\
\hline number of industries & 7 & 0 & 1 & 3 & 4 & 5 \\
\hline ITALY & 0.159 & 0.042 & 0.100 & 0.115 & 0.075 & 0.115 \\
\hline number of industries & 6 & 1 & 2 & 2 & 1 & 3 \\
\hline JAPAN & 0.110 & 0.023 & 0.037 & 0.147 & 0.323 & 0.421 \\
\hline number of industries & 6 & 1 & 3 & 6 & 8 & 8 \\
\hline MALAYSIA & 0.040 & 0 & 0 & 0 & 0 & 0 \\
\hline number of industries & 3 & 0 & 0 & 0 & 0 & 0 \\
\hline NETHERLANDS & 0.667 & 0.282 & 0.303 & 0.338 & 0.356 & 0.321 \\
\hline number of industries & 15 & 7 & 8 & 12 & 14 & 15 \\
\hline NORWAY & 0.029 & 0.055 & 0.042 & 0.158 & 0.210 & 0.139 \\
\hline number of industries & 2 & 1 & 1 & 2 & 2 & 2 \\
\hline RUSSIA & 0 & 0 & 0 & 0 & 0 & 0.106 \\
\hline number of industries & 0 & 0 & 0 & 0 & 0 & 1 \\
\hline SOUTH KOREA & 0 & -- & -- & 0 & 0 & 0.162 \\
\hline number of industries & 0 & 0 & 0 & 0 & 0 & 1 \\
\hline SPAIN & 0.056 & 0.006 & 0.002 & 0.001 & 0.008 & 0 \\
\hline number of industries & 3 & 1 & 1 & 1 & 1 & 0 \\
\hline SWEDEN & 0.262 & 0.237 & 0.106 & 0.219 & 0.205 & 0.239 \\
\hline number of industries & 9 & 2 & 3 & 5 & 5 & 6 \\
\hline SWITZERLAND & 0.295 & 0.289 & 0.146 & 0.238 & 0.253 & 0.268 \\
\hline number of industries & 14 & 6 & 6 & 7 & 11 & 9 \\
\hline USA & 0.455 & 0.422 & 0.458 & 0.554 & 0.464 & 0.539 \\
\hline number of industries & 17 & 16 & 17 & 18 & 17 & 19 \\
\hline
\end{tabular}


Figure 2: Taxonomy of motivations for FDI

\begin{tabular}{|c|c|c|}
\hline & $\begin{array}{c}\text { ULC host } \\
< \\
\text { ULC source }\end{array}$ & $\begin{array}{c}\text { ULC host } \\
> \\
\text { ULC source }\end{array}$ \\
\hline $\begin{array}{l}\text { RDI host } \\
> \\
\text { RDI source }\end{array}$ & $\begin{array}{l}\text { tech sourcing / } \\
\text { location advantage }\end{array}$ & technology sourcing \\
\hline $\begin{array}{c}\text { RDI host } \\
< \\
\text { RDI source }\end{array}$ & $\begin{array}{l}\text { ownership advantage } \\
\text { / efficiency seeking }\end{array}$ & ownership advantage \\
\hline
\end{tabular}


Figure 3. Motivation for inward and outward UK manufacturing FDI, 1987-95 (total figures)

a) Inward total FDI

\begin{tabular}{|c|c|c|}
\hline & ULC UK $<$ ULC F & ULC UK $>$ ULC F \\
\hline RDI UK > RDI F & $\begin{array}{l}\text { tech sourcing / } \\
\text { location advantage } \\
\text { (in 9\%) }\end{array}$ & $\begin{array}{l}\text { technology sourcing } \\
\text { (in 13\%) }\end{array}$ \\
\hline RDI UK $<$ RDI F & $\begin{array}{l}\text { ownership } \\
\text { advantage / } \\
\text { efficiency seeking } \\
\text { (in 18\%) }\end{array}$ & $\begin{array}{l}\text { ownership } \\
\text { advantage } \\
\text { (in 60\%) }\end{array}$ \\
\hline
\end{tabular}

b) Outward total FDI

\begin{tabular}{c|c|c|}
\cline { 2 - 3 } \multicolumn{1}{c|}{ RDI UK > RDI F } & $\begin{array}{c}\text { ULC UK < ULC F } \\
\text { ownership } \\
\text { advantage } \\
\text { (out 7\%) }\end{array}$ & $\begin{array}{c}\text { ULC UK > ULC F } \\
\text { ownership } \\
\text { advantage / } \\
\text { efficiency seeking } \\
\text { (out 31\%) }\end{array}$ \\
\cline { 2 - 3 } RDI UK < RDI F & $\begin{array}{c}\text { technology sourcing } \\
\text { (out 11\%) }\end{array}$ & $\begin{array}{c}\text { tech sourcing / } \\
\text { location advantage } \\
\text { (out 50\%) }\end{array}$ \\
\hline
\end{tabular}


Figure 4. Motivation for inward and outward UK manufacturing FDI, 1987-95 (intra-industry and one-way FDI)

c) Intra-industry FDI (Inward)

\begin{tabular}{|c|c|c|}
\hline & ULC UK < ULC F & ULC UK > ULC F \\
\hline RDI UK > RDI F & $\begin{array}{c}\text { tech sourcing / } \\
\text { location advantage } \\
\text { (in 9\%) }\end{array}$ & $\begin{array}{l}\text { technology sourcing } \\
\text { (in } 13 \%)\end{array}$ \\
\hline RDI UK $<$ RDI F & $\begin{array}{c}\text { ownership } \\
\text { advantage / } \\
\text { efficiency seeking } \\
\text { (in 18\%) }\end{array}$ & $\begin{array}{l}\text { ownership } \\
\text { advantage } \\
\text { (in } 60 \%)\end{array}$ \\
\hline
\end{tabular}

\section{d) Intra-industry FDI (Outward)}

\begin{tabular}{|c|c|c|}
\cline { 2 - 3 } RDI UK > RDI F & $\begin{array}{c}\text { ULC UK < ULC F } \\
\text { ownership } \\
\text { advantage } \\
\text { (out 6\%) }\end{array}$ & $\begin{array}{c}\text { ownership } \\
\text { advantage / } \\
\text { efficiency seeking } \\
\text { (out 19\%) }\end{array}$ \\
\cline { 2 - 3 } RDI UK < RDI F & $\begin{array}{c}\text { technology sourcing } \\
\text { (out 15\%) }\end{array}$ & $\begin{array}{c}\text { tech sourcing / } \\
\text { location advantage } \\
\text { (out 60\%) }\end{array}$ \\
& \\
\end{tabular}

\section{f) One-way FDI (Outward)}

\section{e) One-way FDI (Inward)}

\begin{tabular}{|c|c|}
\cline { 2 - 3 } RDI UK > RDI F & \multicolumn{1}{c}{ ULC UK < ULC F } \\
$\begin{array}{c}\text { tech sourcing / } \\
\text { location advantage } \\
\text { (in 9\%) }\end{array}$ & $\begin{array}{c}\text { tech sourcing } \\
\text { (in 16\% ) }\end{array}$ \\
\cline { 2 - 3 } RDI UK < RDI F & $\begin{array}{c}\text { ownership } \\
\text { ownership } \\
\text { advantage / } \\
\text { efficiency seeking } \\
\text { (in 22\%) }\end{array}$ \\
\hline
\end{tabular}

\begin{tabular}{|c|c|c|}
\cline { 2 - 3 } & \multicolumn{1}{c}{ ULC UK < ULC F } & \multicolumn{1}{c}{ ULC UK > ULC F } \\
\cline { 2 - 3 } RDI UK > RDI F & $\begin{array}{c}\text { ownership } \\
\text { advantage } \\
\text { (out 9\%) }\end{array}$ & $\begin{array}{c}\text { ownership } \\
\text { advantage / } \\
\text { efficiency seeking } \\
\text { (out 77\%) }\end{array}$ \\
\cline { 2 - 3 } RDI UK $<$ RDI F & $\begin{array}{c}\text { technology sourcing } \\
\text { (out 1\%) }\end{array}$ & $\begin{array}{c}\text { tech sourcing / } \\
\text { location advantage } \\
\text { (out 13\% ) }\end{array}$ \\
\hline
\end{tabular}




\section{Table A1}

\section{Countries and Sectors included in the analysis}

\section{Countries}

Australia*

Austria

Belgium

Brunei

Bulgaria

Canada*

China

Cyprus

Czech Republic

Denmark*

Finland*

France*

Germany*

Gibraltar

Greece

Hong Kong

Hungary

Iceland

Indonesia

Irish Republic

Italy*

Japan*

Malaysia

Malta

Netherlands*

Norway*

Philippines

Poland

Portugal

Romania

Russia

Serbia \& Montenegro

Singapore

South Korea

Spain*

Sweden*

Switzerland

Taiwan

Thailand

Turkey

USA*

Vietnam

\section{Sectors}

Agriculture, forestry \& fishing

Banks

Chemicals*

Construction

Distribution

Electrical engineering*

Energy

Food, drink, tobacco*

Hotels/catering \& property

Insurance companies

Mechanical and instrument manufacturing*

Metal manufacturing*

Mining \& quarrying

Other financial institutions

Other manufacturing*

Other services

Paper, printing and publishing*

Rubber*

Shipbuilding*

Shipping

Textiles, leather, clothes*

Transport \& Communication (exc. shipping)*

Vehicles*

\footnotetext{
${ }^{*}$ Countries and Sectors used in Tables 3 and 4
} 


\section{REFERENCES}

ALIBER, R. Z. (1970). A theory of direct foreign investment, The International Corporation, edited by Kindleberger C.P., Cambridge, MIT Press.

AITKEN, B. J. and HARRISON, A.E. (1999). Do domestic firms benefit from foreign investment? Evidence from Venezuela, American Economic Review, Vol.89, 605 - 618.

ANDERTON, B. and BRENTON, P. (1999). Outsourcing and low skilled workers in the UK, Bulletin of Economic Research, Vol.51, 267 - 285.

BAILEY, D. and DRIFFIELD, N.L. (2002). Hymer and uneven development revisited: FDI and regional inequalities, Contributions to Political Economy, Vol.21, 55 - 69.

BAJO-RUBIO, O. and SOSVILLA-RIVERO, S. (1994). An econometric analysis of foreign direct investment in Spain, 1964 - 89, Southern Economic Journal, Vol.61, 104 - 120.

BARRELL, R. and PAIN, N. (1996). An econometric analysis of US foreign direct investment, Review of Economics and Statistics, Vol.78, 200 - 207.

BHAGWATI, J. (2004). In Defence of Globalisation, Oxford, Oxford University Press.

BHAGWATI, J., DINOPOULOS, E. and WONG K-Y. (1992). Quid pro quo foreign investment, American Economic Review, Vol.82, 186 - 190.

BLOMSTRÖM, M. and KOKKO A. (1998). Multinational corporations and spillovers, Journal of Economics Surveys, Vol.12, 247 - 277.

BLOMSTRÖM, M., GLOBERMAN, S. and KOKKO, A. (2001). The determinants of host country spillovers from FDI, in Inward Investment, Technological Change and Growth, edited by PAIN, N., London, Macmillan.

BUCKLEY, P.J. and CASSON, M.C. (1976). The Future of the Multinational Enterprise, London, Macmillan.

CANTWELL, J.A. (1989). Technological Innovation and Multinational Corporations, Oxford, Basil Blackwell.

CANTWELL, J.A. (1991). The international agglomeration of R\&D, in Global Research Strategy and International Competitiveness, edited by CASSON, M.C., Oxford, Blackwell.

COE, D.T. and HELPMAN E. (1995). International R\&D spillovers, European Economic Review, Vol.39, $859-887$. 
CRISCUOLO, C. and MARTIN, R. (2004). Multinationals, foreign ownership and productivity in UK businesses, CERIBA, Working Paper QMW. Available at:

http://www.qmw.ac.uk/ ugte153/CERIBA/publications/multinatsconf.pdf.

DRIFFIELD, N. and LOVE, J.H. (2002). Does the motivation for foreign direct investment affect productivity spillovers to the Domestic sector?, Aston University Working Paper 0202. Available at: http://research.abs.aston.ac.uk/working_papers/0202.pdf.

DRIFFIELD, N. and LOVE, J.H. (2003). Foreign direct Investment, technology sourcing and reverse spillovers, The Manchester School, Vol.71, 659 - 672.

DRIFFIELD, N.L. and TAYLOR, K. (2000). FDI and the labour market: a review of the evidence and policy implications, Oxford Review of Economic Policy, Vol.16, No.3, 90-103.

DUNNING, J.H. (1958). American Investment in British Manufacturing Industry, Allen and Unwin.

DUNNING, J.H. (1979). Explaining patterns of international production: in defence of the eclectic theory, Oxford Bulletin of Economics and Statistics, Vol.41, 269 - 295.

DUNNING, J.H. (1988). The eclectic paradigm of international production: a restatement and some possible extensions, Journal of International Business Studies, Vol.19, 1 - 29.

DUNNING, J.H. (1993). Multinational enterprises and the global economy, Reading, AddisonWesley.

DUNNING, J.H. (1998). Location and the multinational enterprise: a neglected factor?, Journal of International Business Studies, Vol.29, 45-66.

DUNNING, J.H. and NORMAN, G. (1985). Intra-industry production as a form of international economic involvement: An exploratory analysis, in Multinationals as Mutual Invaders: Intraindustry Direct Foreign Investment, edited by A. ERDILEK, St. Martin’s Press, New York.

DUNNING, J.H. and NARULA, R. (1995). The R\&D activities of foreign firms in the United States, International Studies of Management and Organisation, Vol.25, 39 - 73.

DUNNING, J.H. and PITELIS, C. (2004). If Hymer were writing now? Mimeo, Universities of Reading and Cambridge.

FEENSTRA, R.C. and HANSON, G.H. (1999). The impact of outsourcing and high-technology capital on wages: estimates for the United States 1979 - 1990, Quarterly Journal of Economics, Vol.114, $907-940$.

FOSFURI, A. and MOTTA, M. (1999). Multinationals without advantages, Scandinavian Journal of Economics, Vol.101, 617 - 630.

GÖRG, H. and GREENAWAY, D. (2004). Much ado about nothing? Do domestic firms really benefit from foreign direct investment?, World Bank Research Observer, Vol.19, 171 - 197. 
GÖRG, H, and STROBL, E. (2001). Multinational companies and productivity spillovers: a meta-analysis, Economic Journal, Vol.111, F723 - F739.

GRAHAM, E.M. (1978). Transatlantic investment by multinational firms: a rivalistic phenomenon?, Journal of Post Keynesian Economics, Vol.1, Nos.1, 82 - 99.

GRAHAM, E.M. (1985). Intra-industry direct foreign investment, market structure, firm rivalry and technological performance, in Multinationals as Mutual Invaders: Intra-industry Direct Foreign Investment, edited by A. ERDILEK, St. Martin's Press, New York

GREENAWAY, D., LLOYD, P. and MILNER, C. (2001). New concepts and measures of the globalisation of production, Economics Letters, Vol.73, 57 - 63.

GRIFFITH, R. (1999). Using the ARD establishment level data to look at foreign ownership and productivity in the UK, The Economic Journal, Vol.109, F416 - F442.

GRIFFITH, R. and SIMPSON, H. (2001). Characteristics of foreign owned firms in British manufacturing, IFS Working Paper.

GRUBEL, H.G. and LLOYD, P.J. (1975). Intra-Industry Trade, London, Macmillan.

HYMER, S. (1960,1976). The International Operations of National Firms: A Study of Direct Foreign Investment, Cambridge, MIT Press.

HYMER, S. (1971). The multinational corporation and the law of uneven development, in Economics and World Order, edited by BHAGWATI, J.W., New York, Macmillan.

HYMER, S. (1972). United Stated investment abroad, in Direct Foreign Investment in Asia and the Pacific, edited by DRYSDALE, P., Canberra, Australian National University Press.

HYMER, S. and ROWTHORN, R.E. (1970) Multinational corporations and international oligopoly: the non-American challenge, in The International Corporation, edited by KINDLEBERGER, C.P., Cambridge, Mass, MIT Press.

JOHNSON, H.G. (1970). The efficiency and welfare implications of the international corporation, in The International Corporation, edited by KINDLEBERGER, C.P., Cambridge, Mass, MIT Press.

KATHURIA, V. (2000). Productivity spillovers from technology transfer to Indian manufacturing firms, Journal of International Development, Vol.12, 343 - 369.

KELLER, W. (2004). International technology diffusion, Journal of Economic Literature, Vol.42, $752-782$.

KOKKO, A., ZEJAN, M. and TANSINI, R. (2001). Trade regimes and spillover effects of FDI: evidence from Uruguay, Weltwirtschaftliches Archiv, Vol.137, 124 - 149.

KOGUT, B. and CHANG, S.J. (1991). Technological capabilities and Japanese foreign direct investment in the United States, Review of Economics and Statistics, Vol.73, $401-413$. 
KUEMMERLE, W. (1999). The drivers of foreign direct investment into research and development: an empirical investigation, Journal of International Business Studies, Vol.30, 1 24.

KUGLER, M. (2005). Spillovers from foreign direct investment: within or between industries?, Journal of Development Economics, forthcoming.

LOVE, J.H. and LAGE-HIDALGO, F. (2000). Analysing the determinants of US direct investment in Mexico, Applied Economics, Vol.32, 1259 - 1267.

LOVE, J.H. (2003) Technology sourcing versus technology exploitation: an analysis of US foreign direct investment flows, Applied Economics, Vol.35, 1667 - 1678.

NARULA, R. and DUNNING, J.H. (2000) Industrial development, globalisation and multinational enterprises: new realities for developing countries, Oxford Development Studies, Vol. 28, No.2, 141 - 167.

NEVEN, D. and SIOTIS, G. (1996). Technology sourcing and FDI in the EC: An empirical evaluation, International Journal of Industrial Organisation, Vol.14, 543 - 560.

OULTON, N. (2001). Why do foreign-owned firms in the UK have high labour productivity?, in Inward Investment, Technological Change and Growth: The Impact of Multinational Corporations on the UK economy, edited by PAIN, N., Palgrave.

PAIN, N. (1993). An econometric analysis of foreign direct investment in the United Kingdom, Scottish Journal of Political Economy, Vol.40, 1 - 23.

PEARCE, R.D. (1999). Decentralised R\&D and strategic competitiveness: globalised approaches to generation and use of technology in multinational enterprises (MNE's), Research Policy, Vol.28, 157 - 178.

VAN POTTELSBERGHE de la POTTERIE, B. And LICHTENBERG, F. (2001). Does foreign direct investment transfer technology across borders?, Review of Economics and Statistics, Vol.83, 490 - 497.

ROWTHORN, R.E. (1992). Intra-industry trade and investment under oligopoly: the role of market size, Economic Journal, Vol.102, 402 - 414.

RUGMAN, A.M. (1985). The determinants of intra-industry direct foreign investment, in Multinationals as Mutual Invaders: Intra-Industry Direct Foreign Investment, edited by A ERDILEK, New York, St. Martin’s Press.

WOOD, A. (1994). North - South Trade, Employment and Inequality: Changing Fortunes in a Skill Driven World, Oxford, Clarendon Press.

WOOD, A. (1998). Globalisation and the rise in labour market inequalities, Economic Journal, Vol. 108, 1463-1482.

YOUNG, S. and HOOD, N. (1993). Inward Investment policy in the European Community in the 1990’s, Transnational Corporations, Vol.2, Nos.2, 35 - 62. 